\title{
Steroid Receptors and Vertebrate Evolution
}

\author{
Michael E. Baker ${ }^{1}$ \\ ${ }^{1}$ Division of Nephrology-Hypertension \\ Department of Medicine, 0693 \\ University of California, San Diego \\ 9500 Gilman Drive \\ La Jolla, CA 92093-0693
}

Correspondence to:

M. E. Baker. E-mail: mbaker@ucsd.edu

\begin{abstract}
Considering that life on earth evolved about 3.7 billion years ago, vertebrates are young, appearing in the fossil record during the Cambrian explosion about 542 to 515 million years ago. Results from sequence analyses of genomes from bacteria, yeast, plants, invertebrates and vertebrates indicate that receptors for adrenal steroids (aldosterone, cortisol), and sex steroids (estrogen, progesterone, testosterone) also are young, with receptors for estrogens and 3ketosteroids first appearing in basal chordates (cephalochordates: amphioxus), which are close ancestors of vertebrates. An ancestral progesterone receptor and an ancestral corticoid receptor, the common ancestor of the glucocorticoid and mineralocorticoid receptors, evolved in jawless vertebrates (cyclostomes: lampreys, hagfish). This was followed by evolution of an androgen receptor and distinct glucocorticoid and mineralocorticoid receptors in cartilaginous fishes (gnathostomes: sharks). Adrenal and sex steroid receptors are not found in echinoderms: and hemichordates, which are ancestors in the lineage of cephalochordates and vertebrates. The presence of steroid receptors in vertebrates, in which these steroid receptors act as master switches to regulate differentiation, development, reproduction, immune responses, electrolyte homeostasis and stress responses, argues for an important role for steroid receptors in the evolutionary success of vertebrates, considering that the human genome contains about 22,000 genes, which is not much larger than genomes of invertebrates, such as Caenorhabditis elegans ( 18,000 genes) and Drosophila ( 14,000 genes).
\end{abstract}

Keywords: Steroids, Vertebrate Evolution, Ancestral Estrogen, Cambrian, Snowball Earth 


\section{Vertebrates evolved late in the evolution of life on earth}

Life in the form of cynanobacteria is thought to evolved on earth about 3.7 billion years ago, with single cell eukaryotes, fungi (e.g. yeast, ancestors of modern Saccharomyces cerevisiae) evolving about 2 billion years ago [1]. Molecular clock analyses suggest that multicellular animals (metazoans) originated from 800 to 1,000 million years ago [2-4]. Sponges (Porifera) [5] and Trichoplax adhaerens (Placazoa) [6,7], one of the simplest multicellular animals, are modern representatives of basal metazoans [8]. More complex body plans are found in cnidarians [9], which are diploblasts, containing two germ layers, an ectoderm and endoderm. Modern examples are jellyfish, corals, sea anemones and comb jellies. The evolution of Bilateria: bilaterally symmetrical animals that are triploblasts, animals with three germ layers: a mesoderm as well as ectoderm and endoderm, followed. Invertebrates are diverse, containing insects, such as Drosophila, the nematode Caenorhabditis elegans, and mollusks, such as scallops, clams, snails and octopus. Vertebrates evolved in the deuterostome line, a sister clade of protostomes, which contains invertebrates $[10,11]$. Deuterostomes are a much smaller clade of animals. They include echinoderms (sea urchins) and chordates (sea squirts, lancelets, and vertebrates). Thus, vertebrates and other chordates are young in comparison to the evolution of life and to the evolution of multicellular animals. Vertebrate fossils first appeared in the Cambrian from 542 to 515 million years ago $[4,11]$. However, microscopic animal ancestors of vertebrates evolved from the 250 to 400 million years prior to the Cambrian explosion [2, 3], when periods of extreme climate called "Snowball Earth" stimulated the evolution of many transcription factors, including steroid receptors $[12,13]$. The basis for the explosive increase in the diversity of large multicellular animals in the Cambrian is still unresolved [4, 13-15].

\section{Nuclear Receptors for steroids and other lipophilic ligands evolved in multicellular animals}

Nuclear receptors are a large and diverse family of transcription factors that contain receptors for adrenal steroids (glucocorticoids, mineralocorticoids) and sex steroids (estradiol, progesterone, testosterone) (Figure 1), as well as other lipophilic hormones including thyroid hormone, retinoic acid, 1,25-dihydroxyvitamin D3, oxysterols, bile acids and ecdysone [5, 1619]. Adrenal and sex steroid receptors are a separate clade distinct from other nuclear receptors $[20,21]$ including the ecdysone receptor, which is an important insect steroid receptor. Some nuclear receptors, which do not have a bona fide biological ligand, are called orphan receptors 
[22-24]. Ligands for some of these receptors may not have been discovered, while some receptors may not require a ligand for biological activity.

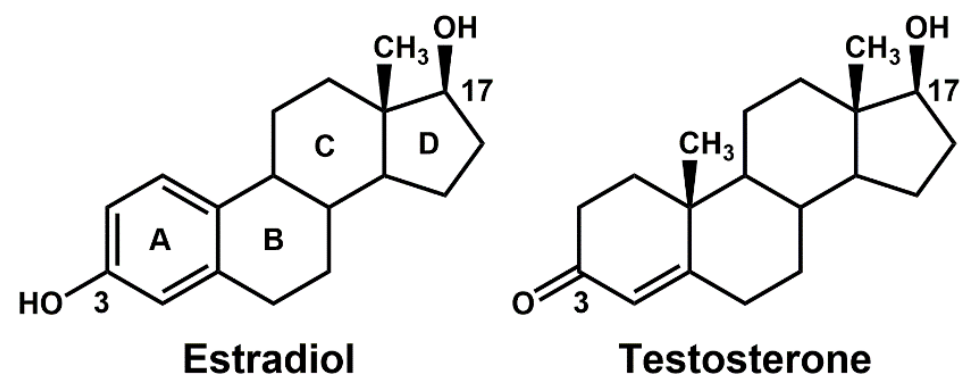<smiles>CC(=O)[C@H]1CCC2C3CCC4=CC(=O)CC[C@]4(C)C3CC[C@@]21C</smiles>

Figure 1 Structures of vertebrate adrenal and sex steroids.

Estradiol has an aromatic A ring with a C3 hydroxyl and lacks a C19 methyl group.

Testosterone, progesterone, cortisol and aldosterone contain an A ring with an unsaturated bond between C4 and C5 and a C3-ketone, and a C19 methyl group. Estradiol is important in female and male physiology $[25,26]$. Aldosterone is the main physiological mineralocorticoid in vertebrates [27-29]. Cortisol is the main physiological glucocorticoid in humans [27]. Testosterone and progesterone are reproductive hormones in males and females, respectively. Progesterone is an antagonist for the MR in humans [30], alligators and Xenopus [31] and an agonist for fish MRs [31-34] and chicken MR [31].

Sequence analysis indicates that nuclear receptors are not present in yeast or plants. Nuclear receptors have been found in basal metazoans: sponges (Porifera) [5] and Trichoplax adhaerens (Placazoa) [6, 35-37], which contain two and four nuclear receptors, respectively. Trichoplax has an estrogen related receptor $\gamma(\mathrm{ERR} \gamma)$, a retinoid $\mathrm{X}$ receptor $(\mathrm{RXR})$, a chicken ovalbumin upstream promoter receptor (COUP) and an Hepatocyte Nuclear Factor 4 receptor (HNF4). ERR and COUP are orphan receptors. During the evolution of multicellular animals, nuclear receptors duplicated, diverged and their number expanded considerably $[5,38]$. Interestingly, there are large differences in the number of nuclear receptors in various 
invertebrates and vertebrates. For example, there are 17 nuclear receptors in the cnidarian starlet sea anemone Nematostella vectensis [9], 270 nuclear receptors in the nematode C. elegans [39], 18 nuclear receptors in Drosophila [40], and 48 nuclear receptors in humans [41]. Thus, from simple origins, nuclear receptors evolved into evolved into a diverse family of transcription factors that are essential to multicellular animals [38].

Interestingly, despite the absence of steroid receptors in yeast, transfection of the yeast Saccharomyces cerevisiae with either human estrogen receptor $\alpha(\operatorname{ER} \alpha)$ [42] or rat glucocorticoid receptor (GR) [43] yields cells that can respond to estradiol and dexamethasone, respectively. Moreover, transfection of the plant Arabidopsis with rat GR [44] leads to cells that are activated by dexamethasone. This indicates that the proteins needed for transcriptional activation of ER $\alpha$ and the GR evolved before multicellular animals.

\section{Adrenal and sex steroid receptors evolved in chordates}

In the 1990s as more eukaryote sequences became available, the origins of nuclear receptors including adrenal and sex steroid receptors began to be investigated [19, 20, 45]. Phylogenetic analysis based on available steroid receptor sequences, which contained few sequences from echinoderms, hemichordates and cephalochordates, predicted that estrogen receptor (ER) was the ancestral vertebrate steroid receptor, with an origin in a close vertebrate ancestor, such as amphioxus [20, 46, 47].

\section{An estrogen receptor and 3-ketosteroid receptor evolved in amphioxus.}

The cloning of an ortholog of the vertebrate ER from amphioxus was an important advance in deciphering the evolution of steroid receptors [48-50] (Figure 2). Unexpectedly, amphioxus ER does not bind estradiol or other steroids, such as progesterone, cortisol, corticosterone, aldosterone and testosterone. Amphioxus also contains a 3-ketosteroid receptor (SR) that is activated by estradiol and estrone, suggesting that amphioxus SR evolved from a duplication of amphioxus ER [48, 50], with amphioxus ER losing estrogen-binding activity. This activity, however, was retained in amphioxus SR, which is not activated by progesterone, cortisol, corticosterone, aldosterone or testosterone. 


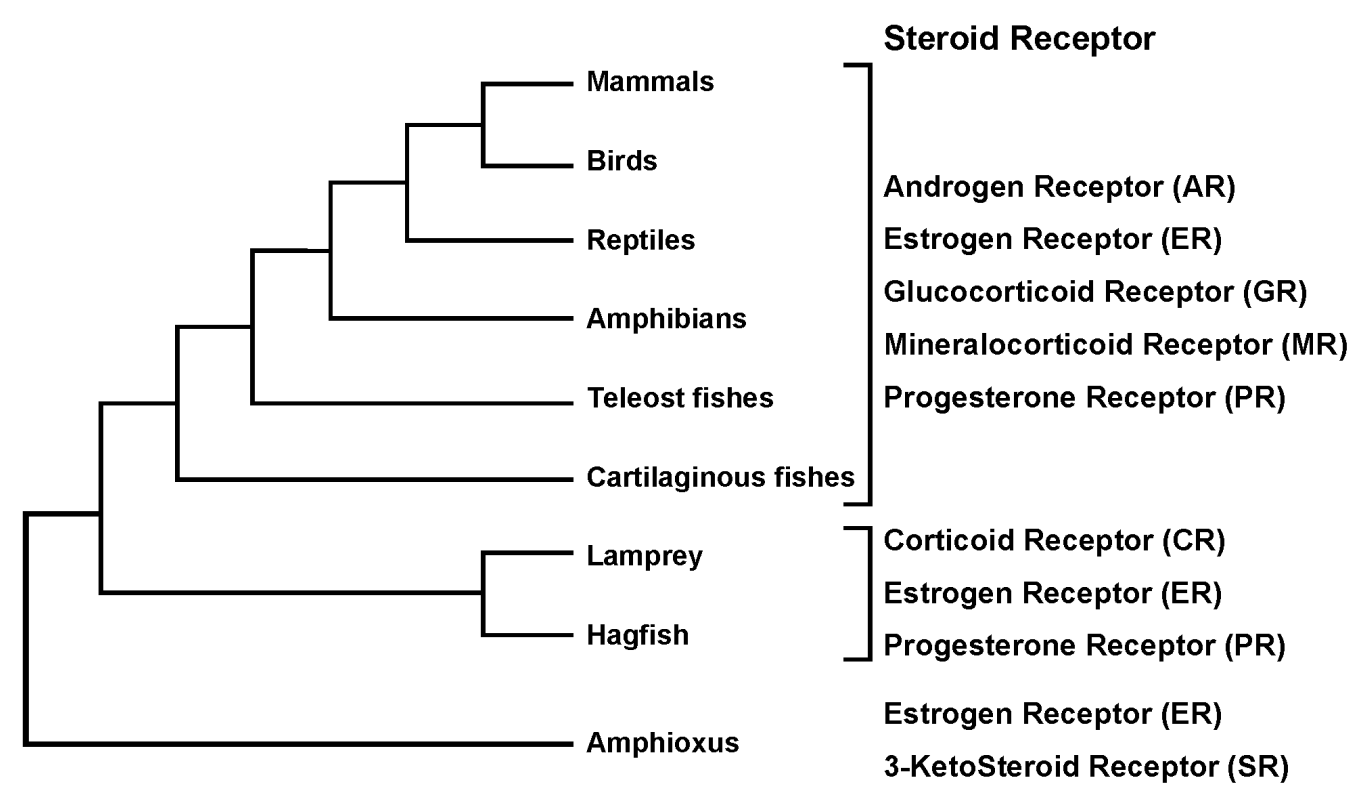

Figure 2 Steroid receptors in amphioxus and vertebrates

The ER and SR evolved in amphioxus. The CR and PR evolved in lampreys and hagfish, which are jawless fishes (cyclostomes) at the base of the vertebrate line. The AR and a separate MR and GR first appear in cartilaginous fishes, which are forerunners of bony fishes and lobe-finned fish (coelacanths and lungfish). Lobe-finned fish are forerunners of tetrapods (land vertebrates).

\section{What was the ancestral estrogen?}

Different molecule(s) have been proposed to be the ancestral estrogen [48, 51-54]. Amphioxus contains aromatase (CYP19) an enzyme necessary for synthesis of the aromatic A ring of estradiol [55], supporting the hypothesis that estradiol or estrone or both were ancestral estrogens [48, 51]. Indeed, the presence of aromatase in amphioxus, but not in invertebrates [17] supports the hypothesis invertebrates do not contain an estrogen-activated ER ortholog.

However, an intriguing property of vertebrate ERs is their promiscuous response to chemicals, which suggests that chemicals with diverse structures that lack an aromatic A ring may have been ligands for amphioxus ER and SR. For example, in addition to estradiol, human ER is activated by $\mathrm{nM}$ concentrations of $\Delta 5$-androstenediol and $5 \alpha$-androstanediol $[25,56,57]$ (Figure 3). Both steroids are attractive alternative physiological estrogens because their synthesis is simpler than that of estradiol $[17,58]$ as neither $\Delta 5$-androstenediol nor $5 \alpha$ - 
androstanediol has an aromatic $\mathrm{A}$ ring (Figure 3). Indeed, $\Delta 5$-androstenediol is synthesized in one step from dehydroepiandrosterone (DHEA) (Figure 4). $\Delta 5$-androstenediol is a physiological estrogen in mammals with important actions in mammalian brain [59-61] and other organs [62, 63]. This supports a role for $\Delta 5$-androstenediol in ancestral chordates, such as amphioxus. Another possible ancestral estrogen is 27-hydroxycholesterol which activates human ER [64-66] (Figure 3). Indeed, 27-hydroxycholesterol is the physiological estrogen in humans with the simplest synthetic pathway [25, 67] (Figure 4).

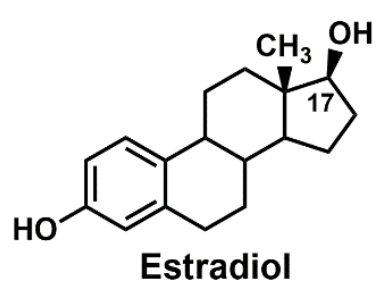<smiles>[Z7]C(CCCC(C)CO)[C@H]1CCC2C3CC=C4C[C@@H](O)CC[C@]4(C)C3CC[C@@]21C</smiles><smiles>C[C@]12CCC3C(CC=C4C[C@H](O)CC[C@@]43C)C1CC[C@@H]2O</smiles>

$\Delta^{5}$-Androstenediol<smiles>C[C@]12CCC3C(CC[C@@H]4C[C@H](O)CC[C@]34C)C1CC[C@@H]2O</smiles>

$5 \alpha$-Androstanediol<smiles>[Z1]C(CCCC(C)C)[C@H]1CCC2C3CCc4cc(O)ccc4C3CC[C@]21C</smiles>

Paraestrol A

\section{Figure 3 Potential ancestral estrogens}

Estradiol contains an aromatic $\mathrm{A}$ ring with a $\mathrm{C} 3$-hydroxyl group. In contrast, $\Delta 5$-androstenediol, $5 \alpha$-androstanediol and 27-hydroxycholesterol contain a cyclohexane A ring, with a $3 \beta$-hydroxyl and a $\mathrm{C} 19$ methyl group. $\Delta 5$-androstenediol and 27-hydroxycholesterol contain a B ring with an unsaturated bond between $\mathrm{C} 5$ and C6. $\Delta 5$-androstenediol, $5 \alpha$-androstanediol and 27 hydroxycholesterol are physiological estrogens [25, 26, 56, 65, 66]. Paraestrol A, which has an aromatic A ring, is synthesized by corals binds to the ancestral SR [68, 69]. 


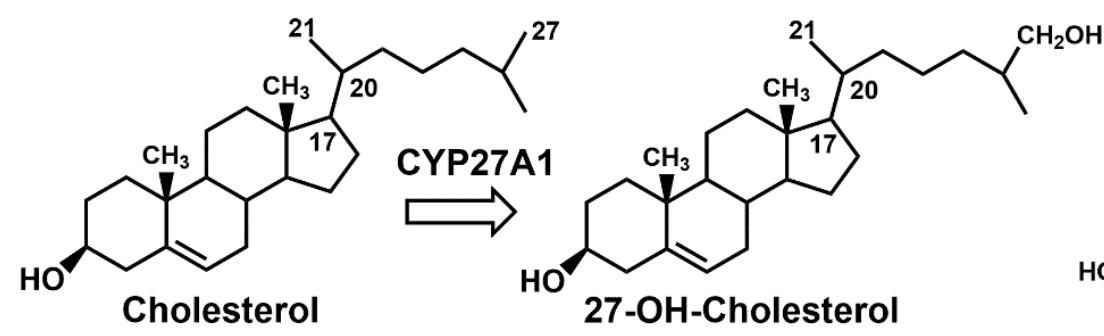<smiles>C[C@@]12CCC(=O)[C@]1(C)CCC1C2CC=C2C[C@H](O)CC[C@@]21C</smiles><smiles>C[C@]12CC[C@@]3(C)C(CC=C4C[C@H](O)CC[C@@]43C)C1CC[C@H]2O</smiles><smiles>CC[AsH2]=C[AsH2]</smiles>
$\Delta^{5}$-Androstenediol<smiles>C[C@]12CCC3C(CCC4=CC(=O)CC[C@@]43C)[C@]1(C)CCC2=O</smiles>

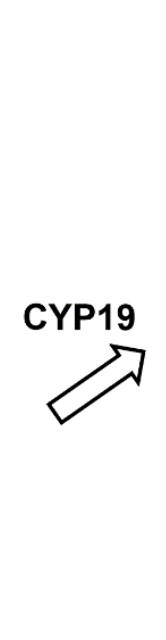

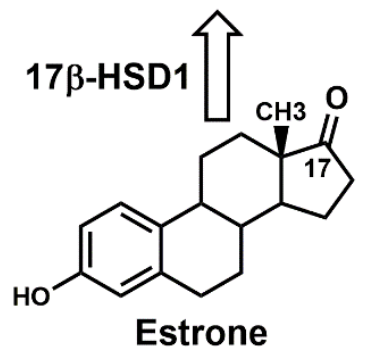

Figure 4 Comparison of estradiol, $\Delta 5$-androstenediol and cholesterol synthesis

Estradiol is synthesized in three steps ( $3 \beta / \Delta^{5-4}$-hydroxysteroid dehydrogenase $\left(3 \beta / \Delta^{5-4}\right.$-HSD), cytochromeP450 19 (CYP19), 17 $\beta$-hydroxysteroid dehydrogenase type 1 (17 $\beta$-HSD1)) from dehydroepiandrosterone (DHEA) $[17,58,70]$. In contrast, $\Delta 5$-androstenediol is synthesized from dehydroepiandrosterone (DHEA) in one step (17 $\beta$-hydroxysteroid dehydrogenase type 14 (17ß-HSD14)) [26, 70]. 27-hydroxycholesterol is synthesized in one step from cholesterol [26, $58]$.

Interestingly, animals such as sponges [71] and coral [72] synthesize steroids with an aromatized A ring and a C17 side chain and could have activated the ancestral ER [69]. Markov et al synthesized one of these steroids, paraestrol A (Figure 3), which has been found in coral [37, 69, 72], and reported that paraestrol A is a transcriptional activator of an ancestral SR [69]. The synthesis by coral of a steroid with an aromatic A ring that was not catalyzed by vertebrate CYP19 raises the possibility that invertebrates could synthesize other aromatized steroids that were transcriptional activators of an ancestral ER [68, 69].

\section{Diversification of 3-ketosteroid receptors in jawless fishes: evolution of progesterone and corticoid receptors}


An important advance in understanding the timing of the evolution of adrenal and sex steroid receptors in vertebrates was the sequencing by Thornton [51] of a progesterone receptor (PR), a corticoid receptor (CR), which is an ancestor of the mineralocorticoid receptor (MR) and glucocorticoid receptor (GR), as well as an ER, in lamprey, which is a basal vertebrate with a more complicated development and life history than amphioxus. The evolution of the PR and $\mathrm{CR}$ in a jawless vertebrate through duplication of an ancestral SR [17, 28, 51] added 3ketosteroids to the repertoire of physiological ligands providing more precise regulation of the complex physiological pathways, including reproduction, immune responses, electrolyte homeostasis and stress responses, in jawless vertebrates and their descendants in cartilaginous fishes, ray-finned fishes and terrestrial vertebrates.

The physiology of steroids in lamprey is only beginning to be understood. Close et al. found that 11-deoxycortisol functioned in lamprey as both a mineralocorticoid and glucocorticoid through activation of the CR [73]. The physiological actions of progestins in lamprey are still being elucidated [74]. Interestingly, both progesterone and $15 \alpha-$ hydroxyprogesterone circulate in lamprey serum [74, 75]. Although an androgen receptor has not been found in lamprey, both testosterone and 15 $\alpha$-hydroxytestosterone are synthesized by lampreys $[75,76]$. The role of $15 \alpha$-hydroxysteroids in lamprey is novel and needs further study.

\section{Evolution of orthologs of androgen, glucocorticoid and mineralocorticoid receptors in cartilaginous fishes.}

Further diversification of the steroid receptor family occurred in cartilaginous fishes (Gnathostomes: sharks), in which a distinct ortholog of the androgen receptor (AR) evolved from a duplicated PR, and a distinct mineralocorticoid receptor (MR) and glucocorticoid receptor (GR) evolved from a duplicated CR [17, 28]. The evolution in cartilaginous fishes of orthologs of the AR, GR and MR completed the evolution of the five classes of adrenal and sex steroid receptors (Figure 2). However, as discussed next, this was not the end of the evolution of steroid hormone signaling in vertebrates, which continued with the evolution of CYP11B2, aldosterone synthetase, a key enzyme in the evolution of terrestrial vertebrates (Figure 5) [17, 29, 58, 77, 78]. 

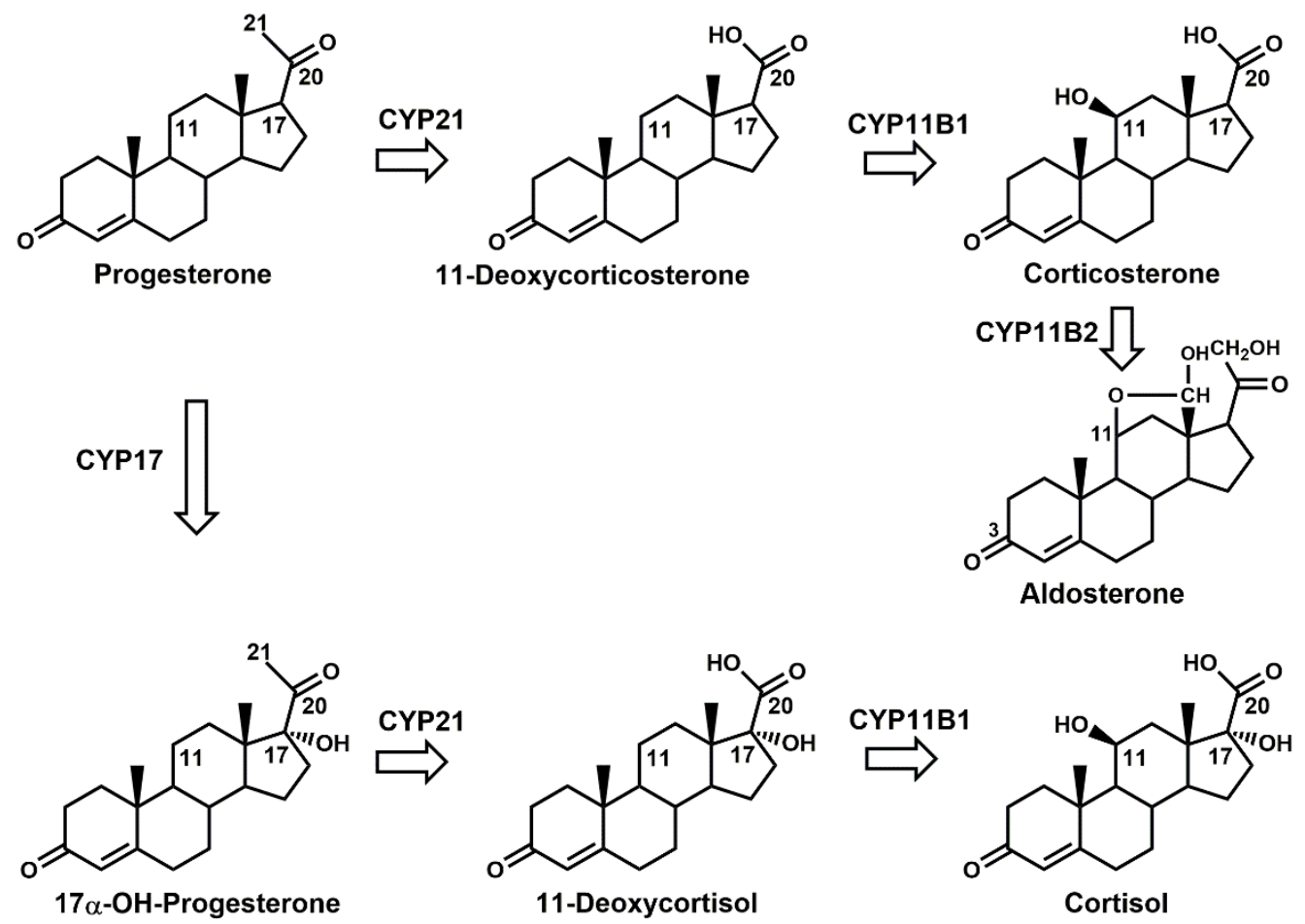

Figure 5. Pathways for the synthesis of aldosterone and cortisol.

Progesterone is hydroxylated at C21 to form 11-deoxycorticosterone, which is hydroxylated at C11 to form corticosterone. Corticosterone is hydroxylated cat C18 followed by oxidation of the $\mathrm{C} 18$ hydroxyl to form aldosterone. In a second pathway, progesterone is hydroxylated at C17 and then hydroxylated at C21 to form 11-deoxycortisol, which is hydroxylated at C11 to form cortisol [17, 27, 29].

\section{Aldosterone synthesis and the conquest of land.}

Aldosterone, the physiological mineralocorticoid in humans and other terrestrial vertebrates was important in evolution of vertebrates from an aqueous environment to an aerobic environment on land. Aldosterone activation of the MR in the kidney maintains salt and water homeostasis, which is critical for controlling blood pressure, as well as to prevent dehydration in animals living out of water [29].

Although aldosterone is a strong activator of the MR in lamprey and hagfish, aldosterone is not found in either lamprey or hagfish serum [79]. Moreover, although aldosterone is a strong activator of cartilaginous fish MR [79, 80] and ray-finned fish MRs [31, 33, 34, 81-83], aldosterone has not been found in either cartilaginous fishes or ray-finned fishes [28, 84]. Aldosterone synthesis requires CYP11B2, which has not been found in fish [84]. Aldosterone 
first appears in lungfish, forerunners of terrestrial vertebrates [28, 78, 85], well after in the evolution of corticosteroids steroids in lampreys, hagfish and cartilaginous fishes [17, 29]

An important role for aldosterone and the MR in the conquest of land by vertebrates came from the work of Homer Smith, a comparative physiologist who studied lungfish during his travels to Africa [29, 86]. Lungfish can live in aqueous and aerobic environments, leading Smith to propose that the evolution of a mechanism to prevent dehydration in lungfish on land was important in the conquest of land by terrestrial vertebrates. The evolution of CYP11B2, leading to aldosterone synthesis in lungfish, provides a mechanism for tight control of electrolyte levels in serum. By maintaining homeostasis in this "Internal Environment", aldosterone activation of the kidney MR facilitated the conquest of land by vertebrates [29].

\section{Perplexing questions:}

\section{A. What is the ligand for the mineralocorticoid receptor in ray-finned fishes?}

Ray-finned fish do not synthesize aldosterone, raising the question as to what is the physiological ligand for the MR in ray-finned fish? Cortisol and 11-deoxycorticosterone have been proposed as physiological mineralocorticoids (Figure 5) [33, 87-93]. However, complicating the identity of the ligand for the MR in ray-finned fishes is evidence that progesterone (Figure 1) is a transcriptional activator of several ray-finned MRs [31-34]. Although progesterone is thought of as a female reproductive hormone [94], progesterone also is active in males [95]. Moreover, progesterone is a precursor of aldosterone and cortisol (Figure 5), and thus, has a much simpler synthesis. This suggests that in addition to activating the PR, progesterone also may regulate transcriptional activation of the MR in ray-finned fish [28, 31, 32].

\section{B. Physiological activity of ray-finned fish mineralocorticoid receptor?}

Unexpectedly, cortisol has been found to regulate sodium uptake in zebrafish through transcriptional activation of the GR [96, 97]. Mineralocorticoid activity of the cortisol via activation of the GR, instead of the MR, in fish [91, 96, 97] is perplexing. Indeed, the physiological function of ray-finned fish MR is incompletely understood. Thus far, ray-finned fish MR appears to have physiological function(s) in fish brain [91, 92, 98]. Interestingly, mammalian MR is expressed in the brain, where MR function is still being elucidated [28, 99- 
101]. Investigation of fish MR function may provide important insights into the function of mammalian MR in the brain.

\section{Function of progesterone activation the chicken mineralocorticoid receptor?}

Chicken MR is activated by progesterone [31]. Thus far, chicken MR is the only terrestrial vertebrate MR that is activated by progesterone [28]. The function of this novel activity of progesterone in chickens remains to be elucidated.

\section{Steroid receptors were important in vertebrate success and survival of environmental disruptions.}

The human genome contains about 22,000 genes [41] which is not much more than the $\sim 18,000$ genes in C. elegans [39] and $\sim 14,000$ genes in Drosophila [102]. The small increase in the number of human genes compared to C. elegans and Drosophila is perplexing considering the vast differences in differentiation, development and reproduction between humans and $C$. elegans and Drosophila. The evolution of different classes of adrenal and sex steroid receptors beginning with the ER and SR in amphioxus, followed by the CR and PR in jawless fish and AR, MR and GR cartilaginous fish supports the hypothesis that steroid receptors were important to the success of vertebrates at key nodes in the diversification of vertebrates by providing more flexible regulation of diverse physiological pathways during differentiation, development, reproduction, immune responses, electrolyte homeostasis and stress response.

The complexity of vertebrate physiology also makes vertebrates sensitive to major environmental disruptions. The flexibility provided by adrenal and sex steroid receptors in regulating vertebrate physiology may have been important in vertebrate survival of major environmental disruptions, such as the mass extinction at the end of the Permian about 252 million years ago, which saw the loss of up to $96 \%$ of all marine species and $70 \%$ of terrestrial species $[103,104]$.

\section{References}

1 Dodd, M. S., Papineau, D., Grenne, T., Slack, J. F., Rittner, M., Pirajno, F., O'Neil, J. and Little, C. T. (2017) Evidence for early life in Earth's oldest hydrothermal vent precipitates. Nature. 543, 60-64

2 dos Reis, M., Thawornwattana, Y., Angelis, K., Telford, M. J., Donoghue, P. C. and Yang, Z. (2015) Uncertainty in the Timing of Origin of Animals and the Limits of Precision in Molecular Timescales. Curr Biol. 25, 2939-2950 
3 Blair, J. E. and Hedges, S. B. (2005) Molecular clocks do not support the Cambrian explosion. Molecular biology and evolution. 22, 387-390

4 Cavalier-Smith, T. (2017) Origin of animal multicellularity: precursors, causes, consequences-the choanoflagellate/sponge transition, neurogenesis and the Cambrian explosion. Philos Trans R Soc Lond B Biol Sci. 372

5 Bridgham, J. T., Eick, G. N., Larroux, C., Deshpande, K., Harms, M. J., Gauthier, M. E., Ortlund, E. A., Degnan, B. M. and Thornton, J. W. (2010) Protein evolution by molecular tinkering: diversification of the nuclear receptor superfamily from a ligand-dependent ancestor. PLoS biology. 8

6 Baker, M. E. (2008) Trichoplax, the simplest known animal, contains an estrogen-related receptor but no estrogen receptor: Implications for estrogen receptor evolution. Biochem Biophys Res Commun. 375, 623-627

7 Schierwater, B. and DeSalle, R. (2018) Placozoa. Curr Biol. 28, R97-R98

8 Neff, E. P. (2018) What is a lab animal? Lab Animal. 47, 223-227

9 Reitzel, A. M. and Tarrant, A. M. (2009) Nuclear receptor complement of the cnidarian Nematostella vectensis: phylogenetic relationships and developmental expression patterns. BMC Evol Biol. 9, 230

10 Blair, J. E. and Hedges, S. B. (2005) Molecular phylogeny and divergence times of deuterostome animals. Molecular biology and evolution. 22, 2275-2284

11 Swalla, B. J. and Smith, A. B. (2008) Deciphering deuterostome phylogeny: molecular, morphological and palaeontological perspectives. Philos Trans R Soc Lond B Biol Sci. 363, 1557-1568

12 Baker, M. E. (2006) Evolution of metamorphosis: role of environment on expression of mutant nuclear receptors and other signal-transduction proteins. Integr Comp Biol. 46, 808-814 13 Baker, M. E. (2006) The genetic response to Snowball Earth: role of HSP90 in the Cambrian explosion. Geobiology. 4, 11-14

14 Erwin, D. H., Laflamme, M., Tweedt, S. M., Sperling, E. A., Pisani, D. and Peterson, K. J. (2011) The Cambrian conundrum: early divergence and later ecological success in the early history of animals. Science. 334, 1091-1097

15 Smith, M. P. and Harper, D. A. (2013) Earth science. Causes of the Cambrian explosion. Science. 341, 1355-1356

16 Evans, R. M. (1988) The steroid and thyroid hormone receptor superfamily. Science. 240, 889-895

17 Baker, M. E., Nelson, D. R. and Studer, R. A. (2015) Origin of the response to adrenal and sex steroids: Roles of promiscuity and co-evolution of enzymes and steroid receptors. J Steroid Biochem Mol Biol. 151, 12-24

18 Bertrand, S., Belgacem, M. R. and Escriva, H. (2011) Nuclear hormone receptors in chordates. Molecular and cellular endocrinology. 334, 67-75

19 Laudet, V., Hanni, C., Coll, J., Catzeflis, F. and Stehelin, D. (1992) Evolution of the nuclear receptor gene superfamily. EMBO J. 11, 1003-1013

20 Baker, M. E. (1997) Steroid receptor phylogeny and vertebrate origins. Mol Cell Endocrinol. 135, 101-107

21 Markov, G. V., Tavares, R., Dauphin-Villemant, C., Demeneix, B. A., Baker, M. E. and Laudet, V. (2009) Independent elaboration of steroid hormone signaling pathways in metazoans. Proc Natl Acad Sci U S A. 106, 11913-11918 
22 Chawla, A., Repa, J. J., Evans, R. M. and Mangelsdorf, D. J. (2001) Nuclear receptors and lipid physiology: opening the X-files. Science. 294, 1866-1870

23 Kliewer, S. A., Lehmann, J. M. and Willson, T. M. (1999) Orphan nuclear receptors: shifting endocrinology into reverse. Science. 284, 757-760

24 Mullican, S. E., Dispirito, J. R. and Lazar, M. A. (2013) The orphan nuclear receptors at their 25-year reunion. J Mol Endocrinol. 51, T115-140

25 Baker, M. E. (2013) What are the physiological estrogens? Steroids. 78, 337-340

26 Baker, M. E. and Lathe, R. (2018) The promiscuous estrogen receptor: Evolution of physiological estrogens and response to phytochemicals and endocrine disruptors. J Steroid Biochem Mol Biol. 184, 29-37

27 Baker, M. E., Funder, J. W. and Kattoula, S. R. (2013) Evolution of hormone selectivity in glucocorticoid and mineralocorticoid receptors. J Steroid Biochem Mol Biol. 137, 57-70 28 Baker, M. E. and Katsu, Y. (2017) 30 YEARS OF THE MINERALOCORTICOID RECEPTOR: Evolution of the mineralocorticoid receptor: sequence, structure and function. J Endocrinol. 234, T1-T16

29 Rossier, B. C., Baker, M. E. and Studer, R. A. (2015) Epithelial sodium transport and its control by aldosterone: the story of our internal environment revisited. Physiological reviews. 95, 297-340

30 Geller, D. S., Farhi, A., Pinkerton, N., Fradley, M., Moritz, M., Spitzer, A., Meinke, G., Tsai, F. T., Sigler, P. B. and Lifton, R. P. (2000) Activating mineralocorticoid receptor mutation in hypertension exacerbated by pregnancy. Science. 289, 119-123

31 Katsu, Y., Oka, K. and Baker, M. E. (2018) Evolution of human, chicken, alligator, frog, and zebrafish mineralocorticoid receptors: Allosteric influence on steroid specificity. Sci Signal.

11

32 Katsu, Y. and Baker, M. E. (2018) Progesterone activation of zebrafish mineralocorticoid receptor may influence growth of some transplanted tumors. Proc Natl Acad Sci U S A. 115, E2908-E2909

33 Sturm, A., Bury, N., Dengreville, L., Fagart, J., Flouriot, G., Rafestin-Oblin, M. E. and Prunet, P. (2005) 11-deoxycorticosterone is a potent agonist of the rainbow trout (Oncorhynchus mykiss) mineralocorticoid receptor. Endocrinology. 146, 47-55

34 Sugimoto, A., Oka, K., Sato, R., Adachi, S., Baker, M. E. and Katsu, Y. (2016) Corticosteroid and progesterone transactivation of mineralocorticoid receptors from Amur sturgeon and tropical gar. Biochem J. 473, 3655-3665

35 Novotny, J. P., Chughtai, A. A., Kostrouchova, M., Kostrouchova, V., Kostrouch, D., Kassak, F., Kana, R., Schierwater, B., Kostrouchova, M. and Kostrouch, Z. (2017) Trichoplax adhaerens reveals a network of nuclear receptors sensitive to 9-cis-retinoic acid at the base of metazoan evolution. PeerJ. 5, e3789

36 Reitzel, A. M., Macrander, J., Mane-Padros, D., Fang, B., Sladek, F. M. and Tarrant, A. M. (2018) Conservation of DNA and ligand binding properties of retinoid X receptor from the placozoan Trichoplax adhaerens to human. J Steroid Biochem Mol Biol. 184, 3-10

37 Khalturin, K., Billas, I. M. L., Chebaro, Y., Reitzel, A. M., Tarrant, A. M., Laudet, V. and Markov, G. V. (2018) NR3E receptors in cnidarians: A new family of steroid receptor relatives extends the possible mechanisms for ligand binding. J Steroid Biochem Mol Biol. 184, 11-19 
38 Bertrand, S., Brunet, F. G., Escriva, H., Parmentier, G., Laudet, V. and RobinsonRechavi, M. (2004) Evolutionary genomics of nuclear receptors: from twenty-five ancestral genes to derived endocrine systems. Molecular biology and evolution. 21, 1923-1937

39 Consortium, C. e. S. (1998) Genome sequence of the nematode C. elegans: a platform for investigating biology. Science. 282, 2012-2018

$40 \quad$ King-Jones, K. and Thummel, C. S. (2005) Nuclear receptors--a perspective from Drosophila. Nat Rev Genet. 6, 311-323

41 Li, W. H., Gu, Z., Wang, H. and Nekrutenko, A. (2001) Evolutionary analyses of the human genome. Nature. 409, 847-849

42 Metzger, D., White, J. H. and Chambon, P. (1988) The human oestrogen receptor functions in yeast. Nature. 334, 31-36

43 Schena, M. and Yamamoto, K. R. (1988) Mammalian glucocorticoid receptor derivatives enhance transcription in yeast. Science. 241, 965-967

44 Schena, M., Lloyd, A. M. and Davis, R. W. (1991) A steroid-inducible gene expression system for plant cells. Proc Natl Acad Sci U S A. 88, 10421-10425

45 Escriva, H., Safi, R., Hanni, C., Langlois, M. C., Saumitou-Laprade, P., Stehelin, D., Capron, A., Pierce, R. and Laudet, V. (1997) Ligand binding was acquired during evolution of nuclear receptors. Proc Natl Acad Sci U S A. 94, 6803-6808

46 Baker, M. E. (2001) Adrenal and sex steroid receptor evolution: environmental implications. J Mol Endocrinol. 26, 119-125

47 Baker, M. E. (2003) Evolution of adrenal and sex steroid action in vertebrates: a ligandbased mechanism for complexity. Bioessays. 25, 396-400

48 Bridgham, J. T., Brown, J. E., Rodriguez-Mari, A., Catchen, J. M. and Thornton, J. W.

(2008) Evolution of a new function by degenerative mutation in cephalochordate steroid receptors. PLoS Genet. 4, e1000191

49 Paris, M., Pettersson, K., Schubert, M., Bertrand, S., Pongratz, I., Escriva, H. and Laudet, V. (2008) An amphioxus orthologue of the estrogen receptor that does not bind estradiol: insights into estrogen receptor evolution. BMC Evol Biol. 8, 219

50 Katsu, Y., Kubokawa, K., Urushitani, H. and Iguchi, T. (2010) Estrogen-dependent transactivation of amphioxus steroid hormone receptor via both estrogen and androgen response elements. Endocrinology. 151, 639-648

51 Thornton, J. W. (2001) Evolution of vertebrate steroid receptors from an ancestral estrogen receptor by ligand exploitation and serial genome expansions. Proc Natl Acad Sci U S A. 98, 5671-5676

52 Baker, M. E. (2011) Insights from the structure of estrogen receptor into the evolution of estrogens: implications for endocrine disruption. Biochem Pharmacol. 82, 1-8

53 Baker, M. E. (2002) Recent insights into the origins of adrenal and sex steroid receptors. J Mol Endocrinol. 28, 149-152

54 Scott, A. P. (2018) Is there any value in measuring vertebrate steroids in invertebrates? Gen Comp Endocrinol. 265, 77-82

55 Mizuta, T. and Kubokawa, K. (2007) Presence of sex steroids and cytochrome P450 genes in amphioxus. Endocrinology. 148, 3554-3565

56 Kuiper, G. G., Carlsson, B., Grandien, K., Enmark, E., Haggblad, J., Nilsson, S. and Gustafsson, J. A. (1997) Comparison of the ligand binding specificity and transcript tissue distribution of estrogen receptors alpha and beta. Endocrinology. 138, 863-870 
57 Kuiper, G. G., Lemmen, J. G., Carlsson, B., Corton, J. C., Safe, S. H., van der Saag, P. T., van der Burg, B. and Gustafsson, J. A. (1998) Interaction of estrogenic chemicals and phytoestrogens with estrogen receptor beta. Endocrinology. 139, 4252-4263

58 Payne, A. H. and Hales, D. B. (2004) Overview of steroidogenic enzymes in the pathway from cholesterol to active steroid hormones. Endocr Rev. 25, 947-970

59 Saijo, K., Collier, J. G., Li, A. C., Katzenellenbogen, J. A. and Glass, C. K. (2011) An ADIOL-ERbeta-CtBP transrepression pathway negatively regulates microglia-mediated inflammation. Cell. 145, 584-595

60 Sugiyama, N., Barros, R. P., Warner, M. and Gustafsson, J. A. (2010) ERbeta: recent understanding of estrogen signaling. Trends Endocrinol Metab. 21, 545-552

61 Zuloaga, K. L., Swift, S. N., Gonzales, R. J., Wu, T. J. and Handa, R. J. (2012) The androgen metabolite, 5alpha-androstane-3beta,17beta-diol, decreases cytokine-induced cyclooxygenase-2, vascular cell adhesion molecule-1 expression, and P-glycoprotein expression in male human brain microvascular endothelial cells. Endocrinology. 153, 5949-5960

62 Lasley, B. L., Chen, J., Stanczyk, F. Z., El Khoudary, S. R., Gee, N. A., Crawford, S. and McConnell, D. S. (2012) Androstenediol complements estrogenic bioactivity during the menopausal transition. Menopause. 19, 650-657

63 Lasley, B. L., Crawford, S. and McConnell, D. S. (2011) Adrenal androgens and the menopausal transition. Obstet Gynecol Clin North Am. 38, 467-475

64 DuSell, C. D., Umetani, M., Shaul, P. W., Mangelsdorf, D. J. and McDonnell, D. P. (2008) 27-hydroxycholesterol is an endogenous selective estrogen receptor modulator. Mol Endocrinol. 22, 65-77

65 Nelson, E. R., DuSell, C. D., Wang, X., Howe, M. K., Evans, G., Michalek, R. D., Umetani, M., Rathmell, J. C., Khosla, S., Gesty-Palmer, D. and McDonnell, D. P. (2011) The oxysterol, 27-hydroxycholesterol, links cholesterol metabolism to bone homeostasis through its actions on the estrogen and liver X receptors. Endocrinology. 152, 4691-4705

66 Wu, Q., Ishikawa, T., Sirianni, R., Tang, H., McDonald, J. G., Yuhanna, I. S., Thompson, B., Girard, L., Mineo, C., Brekken, R. A., Umetani, M., Euhus, D. M., Xie, Y. and Shaul, P. W. (2013) 27-Hydroxycholesterol Promotes Cell-Autonomous, ER-Positive Breast Cancer Growth. Cell Rep. 5, 637-645

67 Baker, M. E. (2014) Expanding the structural footprint of xenoestrogens. Endocrine Disruptors. 2, e967138

68 Markov, G. V., Girard, J., Laudet, V. and Leblanc, C. (2018) Hormonally active phytochemicals from macroalgae: A largely untapped source of ligands to deorphanize nuclear receptors in emerging marine animal models. Gen Comp Endocrinol. 265, 41-45

69 Markov, G. V., Gutierrez-Mazariegos, J., Pitrat, D., Billas, I. M. L., Bonneton, F., Moras, D., Hasserodt, J., Lecointre, G. and Laudet, V. (2017) Origin of an ancient hormone/receptor couple revealed by resurrection of an ancestral estrogen. Sci Adv. 3, e1601778

70 Baker, M. E. (2011) Origin and diversification of steroids: co-evolution of enzymes and nuclear receptors. Mol Cell Endocrinol. 334, 14-20

71 Lu, Z., Van Wagoner, R. M., Harper, M. K., Hooper, J. N. and Ireland, C. M. (2010) Two ring-A-aromatized bile acids from the marine sponge Sollasella moretonensis. Nat Prod Commun. 5, 1571-1574

72 Yan, X. H., Liu, H. L., Huang, H., Li, X. B. and Guo, Y. W. (2011) Steroids with aromatic A-rings from the Hainan soft coral Dendronephthya studeri Ridley. J Nat Prod. 74, 175180 
73 Close, D. A., Yun, S. S., McCormick, S. D., Wildbill, A. J. and Li, W. (2010) 11 deoxycortisol is a corticosteroid hormone in the lamprey. Proc Natl Acad Sci U S A. 107, 1394213947

74 Bryan, M. B., Chung-Davidson, Y. W., Ren, J., Bowman, S., Scott, A. P., Huertas, M., Connolly, M. P. and Li, W. (2015) Evidence that progestins play an important role in spermiation and pheromone production in male sea lamprey (Petromyzon marinus). Gen Comp Endocrinol. 212, 17-27

75 Bryan, M. B., Scott, A. P. and Li, W. (2008) Sex steroids and their receptors in lampreys. Steroids. 73, 1-12

76 Bryan, M. B., Scott, A. P., Cerny, I., Seon Yun, S. and Li, W. (2003) 15 alpha-

Hydroxytestosterone produced in vitro and in vivo in the sea lamprey, Petromyzon marinus. Gen Comp Endocrinol. 132, 418-426

77 Schiffer, L., Anderko, S., Hannemann, F., Eiden-Plach, A. and Bernhardt, R. (2014) The CYP11B subfamily. Journal of Steroid Biochemistry and Molecular Biology

78 Colombo, L., Dalla Valle, L., Fiore, C., Armanini, D. and Belvedere, P. (2006)

Aldosterone and the conquest of land. J Endocrinol Invest. 29, 373-379

79 Bridgham, J. T., Carroll, S. M. and Thornton, J. W. (2006) Evolution of hormone-

receptor complexity by molecular exploitation. Science. 312, 97-101

80 Carroll, S. M., Bridgham, J. T. and Thornton, J. W. (2008) Evolution of hormone

signaling in elasmobranchs by exploitation of promiscuous receptors. Molecular biology and evolution. 25, 2643-2652

81 Kiilerich, P., Triqueneaux, G., Christensen, N. M., Trayer, V., Terrien, X., Lombes, M. and Prunet, P. (2015) Interaction between the trout mineralocorticoid and glucocorticoid receptors in vitro. J Mol Endocrinol. 55, 55-68

82 Pippal, J. B., Cheung, C. M., Yao, Y. Z., Brennan, F. E. and Fuller, P. J. (2011)

Characterization of the zebrafish (Danio rerio) mineralocorticoid receptor. Mol Cell Endocrinol. 332, 58-66

83 Stolte, E. H., de Mazon, A. F., Leon-Koosterziel, K. M., Jesiak, M., Bury, N. R., Sturm, A., Savelkoul, H. F., van Kemenade, B. M. and Flik, G. (2008) Corticosteroid receptors involved in stress regulation in common carp, Cyprinus carpio. J Endocrinol. 198, 403-417

84 Jiang, J. Q., Young, G., Kobayashi, T. and Nagahama, Y. (1998) Eel (Anguilla japonica) testis 11 beta-hydroxylase gene is expressed in interrenal tissue and its product lacks aldosterone synthesizing activity. Mol Cell Endocrinol. 146, 207-211

85 Joss, J. M. P., Arnoldreed, D. E. and Balment, R. J. (1994) The Steroidogenic Response to Angiotensin-Ii in the Australian Lungfish, Neoceratodus-Forsteri. J Comp Physiol B. 164, 378-382

86 Berliner, R. W. (1995) Homer Smith: his contribution to physiology. J Am Soc Nephrol. 5, 1988-1992

87 Baker, M. E. (2003) Evolution of glucocorticoid and mineralocorticoid responses: go fish. Endocrinology. 144, 4223-4225

88 Baker, M. E., Chandsawangbhuwana, C. and Ollikainen, N. (2007) Structural analysis of the evolution of steroid specificity in the mineralocorticoid and glucocorticoid receptors. BMC Evol Biol. 7, 24

89 Bury, N. R. and Sturm, A. (2007) Evolution of the corticosteroid receptor signalling pathway in fish. Gen Comp Endocrinol. 153, 47-56 
90 Gilmour, K. M. (2005) Mineralocorticoid receptors and hormones: fishing for answers. Endocrinology. 146, 44-46

91 Sakamoto, T., Mori, C., Minami, S., Takahashi, H., Abe, T., Ojima, D., Ogoshi, M. and Sakamoto, H. (2011) Corticosteroids stimulate the amphibious behavior in mudskipper: potential role of mineralocorticoid receptors in teleost fish. Physiol Behav. 104, 923-928

92 Takahashi, H. and Sakamoto, T. (2013) The role of 'mineralocorticoids' in teleost fish: relative importance of glucocorticoid signaling in the osmoregulation and 'central' actions of mineralocorticoid receptor. Gen Comp Endocrinol. 181, 223-228

93 Kiilerich, P., Geffroy, B., Valotaire, C. and Prunet, P. (2018) Endogenous regulation of 11-deoxycorticosterone (DOC) and corticosteroid receptors (CRs) during rainbow trout early development and the effects of corticosteroids on hatching. Gen Comp Endocrinol. 265, 22-30 94 Conneely, O. M., Mulac-Jericevic, B., DeMayo, F., Lydon, J. P. and O'Malley, B. W. (2002) Reproductive functions of progesterone receptors. Recent Prog Horm Res. 57, 339-355 95 Aquila, S. and De Amicis, F. (2014) Steroid receptors and their ligands: effects on male gamete functions. Exp Cell Res. 328, 303-313

96 Cruz, S. A., Lin, C. H., Chao, P. L. and Hwang, P. P. (2013) Glucocorticoid receptor, but not mineralocorticoid receptor, mediates cortisol regulation of epidermal ionocyte development and ion transport in zebrafish (danio rerio). PloS one. 8, e77997

97 Kumai, Y., Nesan, D., Vijayan, M. M. and Perry, S. F. (2012) Cortisol regulates Na+ uptake in zebrafish, Danio rerio, larvae via the glucocorticoid receptor. Mol Cell Endocrinol. 364, 113-125

98 Sakamoto, T., Yoshiki, M., Takahashi, H., Yoshida, M., Ogino, Y., Ikeuchi, T., Nakamachi, T., Konno, N., Matsuda, K. and Sakamoto, H. (2016) Principal function of mineralocorticoid signaling suggested by constitutive knockout of the mineralocorticoid receptor in medaka fish. Sci Rep. 6, 37991

99 de Kloet, E. R. (2014) From receptor balance to rational glucocorticoid therapy. Endocrinology. 155, 2754-2769

100 Joels, M. and de Kloet, E. R. (2017) 30 YEARS OF THE MINERALOCORTICOID RECEPTOR: The brain mineralocorticoid receptor: a saga in three episodes. J Endocrinol. 234, T49-T66

101 Arriza, J. L., Weinberger, C., Cerelli, G., Glaser, T. M., Handelin, B. L., Housman, D. E. and Evans, R. M. (1987) Cloning of human mineralocorticoid receptor complementary DNA: structural and functional kinship with the glucocorticoid receptor. Science. 237, 268-275

102 Hild, M., Beckmann, B., Haas, S. A., Koch, B., Solovyev, V., Busold, C., Fellenberg, K., Boutros, M., Vingron, M., Sauer, F., Hoheisel, J. D. and Paro, R. (2003) An integrated gene annotation and transcriptional profiling approach towards the full gene content of the Drosophila genome. Genome Biol. 5, R3

103 Shen, S. Z., Crowley, J. L., Wang, Y., Bowring, S. A., Erwin, D. H., Sadler, P. M., Cao, C. Q., Rothman, D. H., Henderson, C. M., Ramezani, J., Zhang, H., Shen, Y., Wang, X. D., Wang, W., Mu, L., Li, W. Z., Tang, Y. G., Liu, X. L., Liu, L. J., Zeng, Y., Jiang, Y. F. and Jin, Y. G. (2011) Calibrating the end-Permian mass extinction. Science. 334, 1367-1372

104 Penn, J. L., Deutsch, C., Payne, J. L. and Sperling, E. A. (2018) Temperature-dependent hypoxia explains biogeography and severity of end-Permian marine mass extinction. Science. 362 